Proc. Estonian Acad. Sci. Biol. Ecol., 2004, 53, 1, 3-13

\title{
Estimation of leaf area index in a willow plantation
}

\author{
Ebe Merilo", Katrin Heinsoo, and Andres Koppel
}

Institute of Zoology and Botany, Estonian Agricultural University, Riia 181, 51014 Tartu, Estonia; katrin@zbi.ee, akoppel@zbi.ee

Received 30 November 2001, in revised form 10 October 2003

\begin{abstract}
The leaf area index (LAI) was estimated using different methods in four plots of a willow plantation representing two species (Salix dasyclados Wimm. and Salix viminalis L.) and two nutrition levels in 1995-97. Allometric relations between the shoot diameter and leaf mass or litter collection were used for direct estimation of LAI. Allometric LAI values in the studied plots varied from 1.0 to 16.6. Fertilized plots displayed higher LAI values compared with the corresponding control plots. LAI obtained from litter collection was higher than allometric LAI for the control plots, but considerably lower than allometric LAI for the fertilized plot of $S$. dasyclados. When an indirect method (hemispherical "fish-eye" photographs) was used, LAI was strongly underestimated for the fertilized plots and slightly overestimated for the control plots. It is concluded that the allometric method yielded the most accurate LAI estimates.
\end{abstract}

Key words: allometric relations, clumping index, "fish-eye" photography, LAI, litter collection, Salix, specific leaf area.

\section{INTRODUCTION}

Canopy dry matter production depends on the amount of light energy intercepted by the canopy and on foliage photosynthetic capacity. Radiation interception is in turn determined by the leaf area index (LAI, total one-sided leaf area per ground area) and by canopy architecture (Cannell, 1989). Several experiments have shown that the production of different canopies is positively correlated with canopy LAI (Gholz, 1982; Vose \& Allen, 1988; Heilman \& Xie, 1994). The difference between the stand's current LAI and maximum potential LAI that a particular site

\footnotetext{
* Corresponding author, ebe@zbi.ee. Present address: Institute of Botany and Ecology, University of Tartu, Lai 40, 51005 Tartu, Estonia.
} 
can sustain could be used as a diagnostic tool for predicting the efficiency of different silvicultural practices on that stand (Vose \& Allen, 1988; Battaglia et al., 1998). LAI is also an important input parameter in various canopy models (Ceulemans, 1996).

Exact determination of stand LAI is time-consuming and rather complicated. Welles (1990) discussed some indirect methods of LAI estimation based on gap fraction data. Gap fraction estimates of LAI are often lower compared with LAI values calculated by direct methods (Gower \& Norman, 1991; Dufrêne \& Bréda, 1995). However, according to Battaglia et al. (1998), this bias can easily be corrected. An estimate of the stand clumping index $(\Omega)$ is calculated as the ratio of indirect (effective) LAI to direct (allometric) LAI (Smith et al., 1993).

There are several destructive and non-destructive methods for direct estimation of LAI. Destructive methods include harvesting of trees in order to obtain the average leaf area per tree (Cannell et al., 1987), or allometric relations between the leaf area/leaf mass and sapwood area/stem diameter (Hytönen, 1995; Bartelink, 1997; Battaglia et al., 1998). Litter-based techniques, which are used both in deciduous (Neumann et al., 1989; Dufrêne \& Bréda, 1995) and coniferous stands (Vose \& Allen, 1988; Fassnacht \& Gower, 1997), enable to obtain LAI estimates non-destructively.

Short rotation forests consist of fast-growing species, which are able to produce high yields during short periods and to regenerate after coppicing. These forests may display LAI values above 10 (Hinckley et al., 1992; Heilman et al., 1996). However, such high LAI values may be meaningless in terms of radiation interception, as $95 \%$ of light is intercepted at a LAI of 6 (in case the extinction coefficient is 0.5; (Jarvis \& Leverenz, 1983)). Willows are among the most suitable species for short rotation forestry in the temperate region (SennerbyForsse, 1995). Although data on the biomass productivity of willow plantations are abundant (Willebrand et al., 1993; Hytönen, 1995; Tahvanainen \& Rytkönen, 1999), only a few papers report the LAI of these stands (Hytönen, 1995).

The aim of the present study was to compare different methods for LAI estimation in a short rotation willow plantation. Altogether two direct (allometric and litter-based) and one indirect (hemispherical "fish-eye" photographs) methods were used to estimate LAI. We hypothesized that reliable LAI values can be obtained from few simple measurements. Species related differences in LAI and the effect of fertilization on LAI values were studied as well.

\section{MATERIAL AND METHODS \\ Plant material and cultivation}

The studied willow plantation at Saare, eastern Estonia, was established from cuttings of 7 Salix clones, originating from the Swedish Energy Forestry Programme, at a density of 20000 plants per hectare in May 1993. A detailed description of the site is given in a previous report (Koppel et al., 1996). In the 
present experiment, two willow species, Salix dasyclados Wimm., clone 81090 (further abbreviated as $S d$ ), and Salix viminalis L., clone 78183 (further $S v$ ), were studied. The experiment was performed with two-, three-, and four-year-old shoots in 1995, 1996, and 1997, respectively. Both studied species were represented by two plots of $16 \mathrm{~m} \times 16 \mathrm{~m}$ or $8 \mathrm{~m} \times 16 \mathrm{~m}$. One plot was fertilized annually with $60-168 \mathrm{~kg} \mathrm{~N} \mathrm{ha}^{-1}, 0-37 \mathrm{~kg} \mathrm{P} \mathrm{ha}^{-1}$, and $0-70 \mathrm{~kg} \mathrm{~K} \mathrm{ha}^{-1}$ during the period between 1994 and 1997, the other received no additional fertilizer. Thus, four plots representing two species $(S d$ and $S v)$ and two nutrition levels $(\mathrm{C}-$ control and $\mathrm{F}$ - fertilized) were studied: $S d \mathrm{C}, S d \mathrm{~F}, S v \mathrm{C}$, and $S v \mathrm{~F}$. The exact scheme of fertilization is presented by Heinsoo et al. (2002).

\section{Estimation of LAI}

\section{Allometric LAI estimation}

Willow shoots were harvested from $S v \mathrm{~F}$ and $S d \mathrm{~F}$ plots (17-25 shoots per plot) in August 1995, 1996, and 1997. By that time LAI had reached its maximum values in the climatic conditions of Estonia (Ross \& Ross, 1998). The harvested shoots were selected to cover evenly the whole diameter distribution range within the plot. Power relations were established between the shoot diameter at $55 \mathrm{~cm}$ above the ground $(\mathrm{d} 55 ; \mathrm{mm})$ and its total leaf dry mass $(\mathrm{LM} ; \mathrm{g})$ using the SAS NLIN packet. The vertical distribution of specific leaf area (SLA, leaf area/leaf dry mass; $\mathrm{cm}^{2} \mathrm{~g}^{-1}$ ) was determined for 3-5 shoots per plot by dividing these shoots into 10 vertical sections of equal length. The number of leaves per stem section used for SLA determination was 3-10 depending on leaf size. The leaf area was determined on fresh leaves by scanning the leaves (Hewlett Packard ScanJet $4 \mathrm{C} / \mathrm{T}$ ) and by calculating the area of the leaf image using a special computer program. The accuracy of the leaf area determination was within $2 \%$.

Considering the unequal contribution of different vertical leaf layers with different SLA to total canopy leaf mass, a weighted value of SLA was determined using the harvested shoots. In the calculations of weighted SLA, the significance given to the SLA of a particular canopy layer was proportional to the leaf mass in that layer. To obtain the leaf area per plant, the total leaf mass per plant was multiplied by the weighted SLA value. LAI was calculated using the leaf area and plant density data. The plant density was considered to be two plants per $\mathrm{m}^{2}$.

In 1995 and 1996, the d55 of all living shoots was measured on 7-19 sample plants per plot (i.e for $S d \mathrm{C}, S d \mathrm{~F}, S v \mathrm{C}$, and $S v \mathrm{~F}$ ) with a caliper. Shoots thinner than $4 \mathrm{~mm}$ were neglected. The sample plants were marked so that the shoot d55 values of the same plants could be measured during the experiment. In 1997, all plants per plot were measured for shoot diameters. The parameters of power relations between d55 and LM were used to calculate the total LM of 7-19 sample plants per plot in 1995 and 1996, whereas the total LM per plot was obtained in 1997. 
Thus, the shoots used to determine the relation between shoot d55 and LM were harvested only from F plots of both species. LAI for control plots was calculated using allometric relations between d55 and LM obtained for the fertilized plants and shoot $\mathrm{d} 55$ values for the plants grown in $\mathrm{C}$ plots. In addition, the values of SLA and weighted SLA were determined for leaves of $S d \mathrm{~F}$ and $S v \mathrm{~F}$ only.

\section{LAI estimation from litter collections}

At the beginning of August 1997, three plastic rectangular traps (size $55 \mathrm{~cm} \times 39 \mathrm{~cm}$ ) were randomly placed on each plot in order to collect litter. Litter was collected from these traps seven times during the period AugustNovember. The average litter SLA for plots $S v \mathrm{~F}, S v \mathrm{C}, S d \mathrm{~F}$, and $S d \mathrm{C}$ was determined in 1998 by collecting fallen leaves of different size several times during the leaf-fall period and analysing these leaves for SLA. The average litter SLA values were used for the calculations of leaf area. First the leaf area per trap and then LAI were calculated.

\section{Indirect LAI estimation}

In mid-August 1997, three hemispherical "fish-eye" photographs per plot were taken at $50 \mathrm{~cm}$ above the ground (i.e. below the foliage). Negative images were digitized by a film scanner (FilmScan 200, Epson, Japan). Effective (indirect) LAI was estimated from the "fish-eye" photographs according to Welles \& Norman (1991) employing the Scanopy (v 2.0A; Régent Instruments Inc., Quebec, Canada) program. The mean plot clumping index $(\Omega)$ was calculated as the ratio of effective LAI to allometric LAI as described by Smith et al. (1993). The closer the value of $\Omega$ is to zero, the more aggregated is the canopy foliage, while values close to 1 refer to a random foliage distribution.

\section{RESULTS AND DISCUSSION}

The specific leaf area decreased along the vertical gradient in the canopy (Fig. 1). This pattern is universal both for deciduous (Bartelink 1997; Verwijst \& Telenius, 1999) and coniferous (Niinemets \& Kull, 1995) tree canopies and is attributed to the light profile within the canopy. The foliage was distributed vertically so that most leaves were located in the middle part of the canopy (Fig. 1). The vertical distribution of the leaf area, individual leaf size, and leaf inclination angle serves to optimize light interception and canopy photosynthesis (Heilman et al., 1996). The weighted SLA values for $S v$ F were 125 and $148 \mathrm{~cm}^{2} \mathrm{~g}^{-1}$ in 1995 and 1996, respectively. The corresponding values for $S d \mathrm{~F}$ were 154 and $155 \mathrm{~cm}^{2} \mathrm{~g}^{-1}$, respectively. The values of weighted SLA were close to the equivalent average SLA values. 

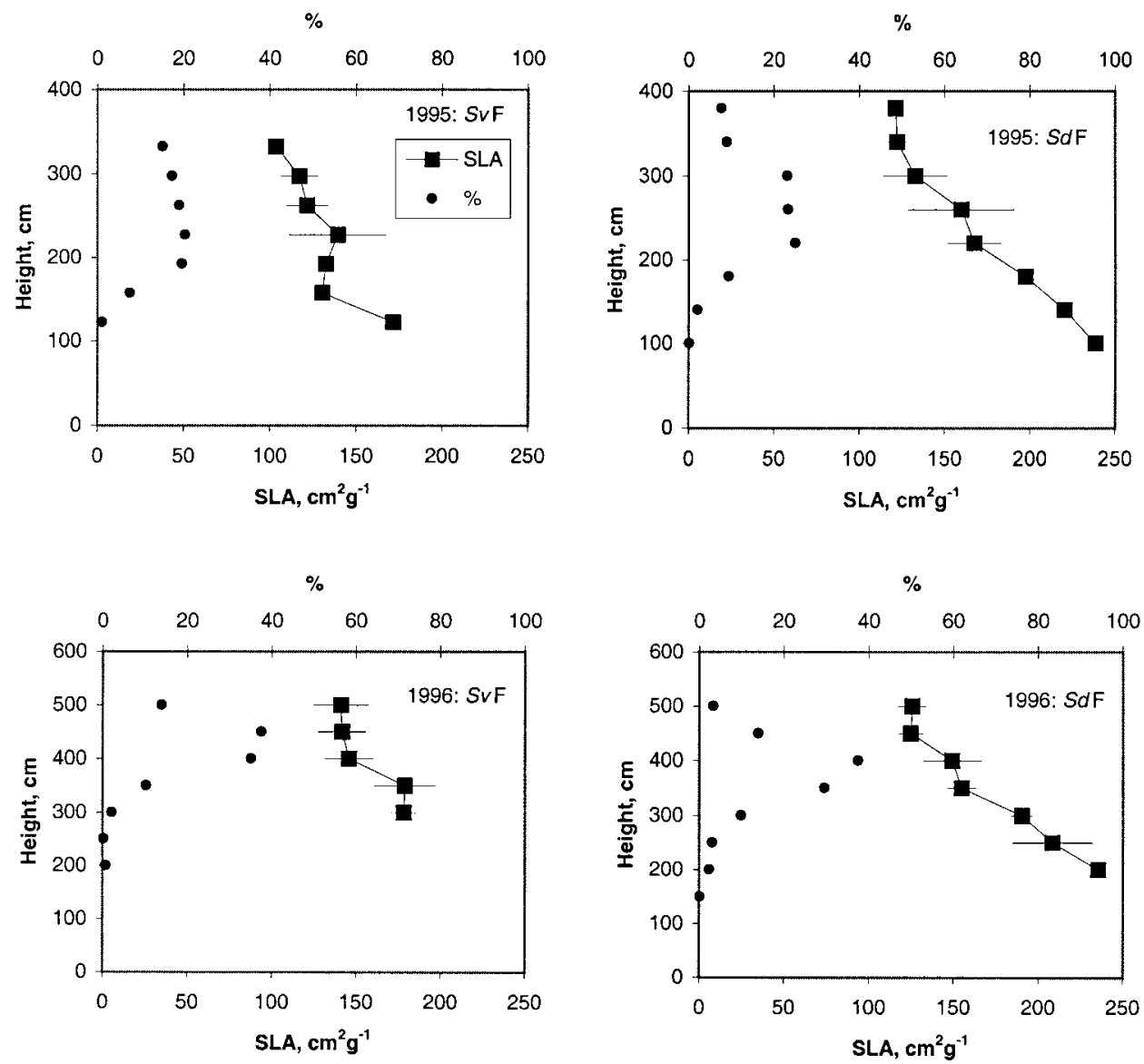

Fig. 1. Vertical distribution of leaf mass (\% of total foliage mass) and specific leaf area (SLA) (average \pm SE) in 1995 and 1996 .

The parameters of power relations between $\mathrm{d} 55$ and LM for plants growing in fertilized plots in 1995-97 are presented in Table 1. Parameters $a$ and $b$ were used in the calculations of allometric LAI. We also tried to find the adequate number of shoots to be harvested in order to get accurate LAI estimates. In 1995, the number of shoots harvested was 23 for both $S v \mathrm{~F}$ and $S d \mathrm{~F}$. We selected 10 shoots out of 23 , with a prerequisite that the selected shoots presented evenly the d55 range of a large sample, and used the selected shoots to establish the parameters of power relations. The values of LAI tallied within $10 \%$ when LAI was calculated using parameters $a$ and $b$ based on the correlations of 10 plants or 23 plants. However, if the number of harvested shoots is lowered, care must be taken that the real shoot d55 distribution within the plot is presented. 
Table 1. Parameters of power regression between LM $(\mathrm{g})$ and $\mathrm{d} 55(\mathrm{~mm}), \mathrm{LM}=a \times \mathrm{d} 55^{b}$, for two studied willow species grown in fertilized plots. The number of replicate shoots was 23,23 , and 25 for Salix viminalis and 23, 17, and 20 for Salix dasyclados in 1995, 1996, and 1997, respectively

\begin{tabular}{c|c|c|c|c|c|c}
\hline \multirow{2}{*}{ Year } & \multicolumn{4}{c|}{$S v \mathrm{~F}$} & \multicolumn{2}{c}{$S d \mathrm{~F}$} \\
\cline { 2 - 7 } & $a$ & $b$ & Adjusted $R^{2}$ & $a$ & $b$ & Adjusted $R^{2}$ \\
\hline \multirow{2}{*}{1995} & 0.0660 & 2.323 & 0.91 & 0.0077 & 3.013 & 0.96 \\
1996 & 0.0005 & 3.649 & 0.96 & 0.0418 & 2.403 & 0.84 \\
1997 & 0.0004 & 3.650 & 0.95 & 0.0011 & 3.277 & 0.94
\end{tabular}

Table 2 presents LAI values calculated according to different methods in 1995-97. Fertilized plots displayed higher allometric LAI values than the corresponding control plots. Increased LAI due to fertilization is in accordance with the results reported in the literature (Vose \& Allen, 1988; Heilman \& Xie, 1994; Fassnacht \& Gower, 1997). For $S d$, allometric LAI reached the maximum value in 1996, whereas for $S v$, in 1997.

In the calculations of allometric LAI values for control plots, some data (relations between d55 and LM for respective years, weighted values of SLA) obtained for plants of equivalent fertilized plots were used. In other words, possible differences in LM for shoots with similar d55 and in SLA between fertilized and control plants were not taken into account. The relation between

Table 2. LAI values for the studied Salix plots estimated by different methods in 1995-97. Clumping index $(\Omega)$ was calculated as effective (indirect) LAI divided by allometric LAI. ne $=$ not estimated. The LAI values of 1997 marked by a star were calculated from d55 of 20 sample plants

\begin{tabular}{c|c|c|c|c|c}
\hline Plot & Year & $\begin{array}{c}\text { Allometric } \\
\text { (power) }\end{array}$ & Litter & Indirect & $\Omega$ \\
\hline \multirow{2}{*}{$S v \mathrm{C}$} & 1995 & 1.5 & ne & ne & \\
& 1996 & 1.0 & ne & ne & \\
& 1997 & 2.3 & 4.3 & 2.4 & 1.04 \\
& & $1.5^{*}$ & & & \\
$S v \mathrm{~F}$ & 1995 & 4.5 & ne & ne & \\
& 1996 & 5.1 & ne & ne & \\
& 1997 & 6.1 & 6.8 & 2.7 & 0.44 \\
& & $7.0^{*}$ & & & \\
$S d \mathrm{C}$ & 1995 & 1.2 & ne & ne & \\
& 1996 & 3.2 & ne & ne & \\
& 1997 & 2.8 & 4.9 & 2.9 & 1.04 \\
& & $2.4^{*}$ & & & \\
$S d \mathrm{~F}$ & 1995 & 7.2 & ne & ne & \\
& 1996 & 16.6 & ne & ne & \\
& 1997 & 9.2 & 6.4 & 2.4 & 0.26
\end{tabular}


the leaf area and sapwood area is influenced by stand growth rates (Espinosa Bancalari et al., 1987) and site water vapour pressure deficit (Mencuccini \& Grace, 1995). On the other hand, nitrogen fertilization has either an insignificant (Heilman \& Xie, 1994; Ibrahim et al., 1997) or a positive effect on the SLA of poplar (Liu \& Dickmann, 1992).

In our willow plantation, LM of shoots with equal d55 was higher for control plants than for fertilized plants, whereas SLA of fertilized plants was considerably higher than that of control plants in 1999 and 2000 (data not shown). Our calculations showed that LAI of control plots was underestimated by $7 \%$ in $\mathrm{Sv}$ and by $39 \%$ in $S d$ when allometric relations of fertilized plants were used in LAI calculations for August 1999. The considerably larger underestimation of LAI in $S d$ was probably due to larger differences between average d55 of fertilized and control plots for that species (1.5 times for $S d$ versus 1.2 times for $S v$ ). Thus, a larger proportion of shoots was considered as supressed for $S d \mathrm{C}$ than for $S v \mathrm{C}$, if correlations of equivalent fertilized plants were used. However, by using higher SLA of fertilized plants in the LAI calculations of control plots, the results became closer to the real LAI values.

Taking this into account, allometric LAI values for control plots obtained during the period of 1995-97 might be lower than real values. In 1997, indirect LAI values for control plots were higher than the corresponding allometric values. Hence, clumping indices for control plots calculated as indirect (effective) LAI divided by allometric LAI were larger than 1 (i.e. useless), indicating that either allometric estimation of LAI for these plots was biased, or LAI was overestimated with the "fish-eye" method. For stands with low LAI, LAI can be overestimated with indirect methods because of the high relative importance of branch and stem area indices (Sampson \& Allen, 1995). This could also have been the case with our non-fertilized plots. In future studies, however, allometric relations and SLA values obtained for fertilized plants should not be directly used in the calculations of LM and LA for non-fertilized plants in order to get accurate estimates of LAI.

The allometric LAI value for $S d \mathrm{~F}$ was very high in 1996 compared with LAI values for different tree canopies reported in the literature (Cannell et al., 1987; Barigah et al., 1994; Hytönen, 1995). Cannell (1989) warned that LAI estimates higher than 10 for broadleaved stands should be treated with caution, while coniferous stands may display higher LAI values (Gholz, 1982). For short rotation forests, however, LAI values higher than 10 have been reported in the literature (Hinckley et al., 1992; Heilman et al., 1996). High LAI values for $S d$ F were probably associated with large single leaf areas and high SLA values.

In 1997 we measured the shoot diameters of all plants per plot. This enabled to evaluate the representativeness of the selected sample plants, which were measured for shoot diameters in 1995 and 1996. In two plots $(S v \mathrm{~F}$ and $S d \mathrm{C})$ the sample plants represented average diameter distribution adequately, and LAI values calculated using d55 data of 20 sample plants (LAI values marked with a star in Table 2) were close to the values obtained using d55 data of all plants per plot. For $S d \mathrm{~F}$, however, as a result of selection the average number of shoots per plant was overestimated by $14 \%$ and the average LM per shoot by $29 \%$ (data not 
shown). Thus, selected sample plants did not represent adequately the plant and shoot sizes of the whole plot. For $S v \mathrm{C}$, the selected sample plants were, on the contrary, smaller, both in terms of number of shoots per plant and LM per shoot, resulting in considerably lower LAI when d55 data of 20 plants were used.

The fact that plant density was taken to be 2 plants per $\mathrm{m}^{2}$, neglecting thus stool mortality during the rotation, resulted in an overestimation of LAI in all plots. Neglecting stool mortality led to an overestimation of LAI by 5\%, 3\%, 9\%, and $19 \%$ for $S v \mathrm{C}, S v \mathrm{~F}, S d \mathrm{C}$, and $S d \mathrm{~F}$, respectively, in 1997.

LAI values calculated using litter data present an estimate of integrated LAI over the whole vegetation period and not of standing LAI at any moment, since all leaves fallen from the plants during the late summer and autumn were collected for the determination of LAI. Thus, the LAI values obtained from litter collections should be somewhat higher than the corresponding allometric LAI values. This was in fact evident for all plots except $S d \mathrm{~F}$. For $S d \mathrm{~F}$, the allometric LAI value was considerably higher than that calculated using litter data. Unfortunately, we have no sensible explanation for this. The total leaf weight and, consequently, LAI per trap varied little between the three litter traps of plot $S d \mathrm{~F}$. Therefore, it is unlikely that some litter was lost during the collection.

Indirect LAI values for different plots were highly similar (Table 2). Low indirect LAI values for fertilized plots indicate that light interception there was not considerably higher compared with control plots. The foliage of $S d \mathrm{C}$ intercepted $87 \%$ of incident light, while the foliage of the other plots intercepted $85 \%$ (data obtained from "fish-eye" photographs). Thus, the higher standing LAI of fertilized plots was not accompanied by higher light capture. In 1997, the direct and indirect LAI values for $S v \mathrm{~F}$ and $S d \mathrm{~F}$ differed 2.3 and 3.8 times, respectively. Sampson \& Allen (1995) suggested that the LAI estimated by indirect methods may approach the upper asymptote, which results in more considerable underestimation of real LAI in stands with high LAI. Clumping indices for $S v \mathrm{~F}$ and $S d \mathrm{~F}$ were 0.44 and 0.26 , respectively, indicating high aggregation of the foliage.

In conclusion, the allometric method used in the present study revealed differences in LAI values between two species, nutrition levels, and years. Nonetheless, shoot harvesting for the determination of allometric relations between the foliage and stem parameters should be performed on respective species and fertilization level. It is also important to ensure that harvested and measured shoot and plant samples cover the whole range of shoot and plant sizes. In case they do, the number of studied shoots and plants may be lower. We suggest that at least 10 shoots should be harvested in order to determine relations between d55 and LM and at least 20 plants measured for shoot diameters. The indirect method of LAI estimation resulted in a considerable underestimation of real LAI values for fertilized plots. Chen et al. (1991) concluded that in case indirect (optical or radiation) methods are used for LAI measurement, determination of clumping index is required. According to Sampson \& Allen (1995), however, application of constant species-specific correction factors will not always yield reliable LAI estimates. Our results indicate that the clumping index varies in different Salix species and fertility conditions. 


\section{ACKNOWLEDGEMENTS}

This study was supported by the Estonian Science Foundation (grant No. 2668). The final version of the manuscript was completed during the post-doctoral studies of the corresponding author. We thank Mrs. Ester Jaigma for revising the English text of the manuscript. Professor Olevi Kull provided help in analysing "fish-eye" photographs.

\section{REFERENCES}

Barigah, T. S., Saugier, B., Mousseau, M., Guittet, J. \& Ceulemans, R. 1994. Photosynthesis, leaf area and productivity of 5 poplar clones during their establishment year. Ann. Sci For., 51, 613-625.

Bartelink, H. H. 1997. Allometric relationships for biomass and leaf area of beech (Fagus sylvatica L.). Ann. Sci For., 54, 39-50.

Battaglia, M., Cherry, M. L., Beadle, C. L., Sands, P. J. \& Hingston, A. 1998. Prediction of leaf area index in eucalypt plantations: effects of water stress and temperature. Tree Physiol., 18, 521-528.

Cannell, M. G. R. 1989. Physiological basis of wood production: a review. Scand. J. For. Res., 4, 459-490.

Cannell, M. G. R., Milne, R., Sheppard, L. J. \& Unsworth, M. H. 1987. Radiation interception and productivity of willow. J. Appl. Ecol., 24, 261-278.

Ceulemans, R. 1996. An inventory of tree and stand growth models with potential application in short-rotation forestry. Biomass Bioenergy, 11, 95-107.

Chen, J. M., Black, T. A. \& Adams, R. S. 1991. Evaluation of hemispherical photography for determining plant area index and geometry of a forest stand. Agric. For. Meteorol., 56, 129-143.

Dufrêne, E. \& Bréda, N. 1995. Estimation of deciduous forest leaf area index using direct and indirect methods. Oecologia, 104, 156-162.

Espinosa Bancalari, M. A., Perry, D. A. \& Marshall, J. D. 1987. Leaf area-sapwood area relationships in adjacent young Douglas-fir stands with different early growth rates. Can. J. For. Res., 17, 174-180.

Fassnacht, K. S. \& Gower, S. T. 1997. Interrelationships among the edaphic and stand characteristics, leaf area index and aboveground net primary production of upland forest ecosystems in north central Wisconsin. Can. J. For. Res., 27, 1058-1067.

Gholz, H. L. 1982. Environmental limits on aboveground net primary production, leaf area, and biomass in vegetation zones of the Pacific Northwest. Ecology, 63, 469-481.

Gower, S. T. \& Norman, J. M. 1991. Rapid estimation of leaf area index in conifer and broad-leaf plantations. Ecology, 72, 1896-1900.

Heilman, P. E. \& Xie, F. 1994. Effects of nitrogen fertilization on leaf area, light interception and productivity of short-rotation Populus trichocarpa $\times$ Populus deltoides hybrids. Can. J. For. Res., 24, 166-173.

Heilman, P. E., Hinckley, T. M., Roberts, D. A. \& Ceulemans, R. 1996. Production physiology. In Biology of Populus and Its Implications for Management and Conservation (Stettler, R. F., Bradshaw, H. D. Jr., Heilman, P. E. \& Hinckley, T. M., eds.), pp. 459-489. NRC Research Press, National Research Council of Canada, Ottawa, ON.

Heinsoo, K., Sild, E. \& Koppel, A. 2002. Estimation of shoot biomass productivity in Estonian Salix plantations. For. Ecol. Manage., 170, 67-74. 
Hinckley, T. M., Braatne, J., Ceulemans, R., Clum, P., Dunlap, J., Newman, D., Smit, B., ScarasciaMugnozza, G. \& van Volkenburgh, E. 1992. Growth dynamics and canopy structure. In Ecophysiology of Short Rotation Forest Crops (Mitchell, C. P., Ford-Robertson, J. B., Hinckley, T. \& Sennerby-Forsse, L., eds.), pp. 1-34. Elsevier Applied Science, London \& New York.

Hytönen, J. 1995. Ten-year biomass production and stand structure of Salix 'Aquatica' energy forest plantation in southern Finland. Biomass Bioenergy, 8, 63-71.

Ibrahim, L., Proe, M. F. \& Cameron, A. D. 1997. Main effects of nitrogen supply and drought stress upon whole-plant carbon allocation in poplar. Can. J. For. Res., 27, 1413-1419.

Jarvis, P. G. \& Leverenz, J. W. 1983. Productivity of temperate, deciduous and evergreen forests. In Encyclopedia of Plant Physiology, New Series, Vol. 12D, Physiological Plant Ecology IV (Lange, O. L., Nobel, P. S., Osmond, C. B. \& Zeiger, H., eds.), pp. 233-280. Springer-Verlag, Berlin.

Koppel, A., Perttu, K. \& Ross, J. 1996. Estonian energy forest plantations: general information. In Short Rotation Willow Coppice for Renewable Energy and Improved Environment, Vol. 57 (Perttu, K. \& Koppel, A., eds.), pp. 15-24. Department of Short Rotation Forestry, Swedish University of Agricultural Sciences.

Liu, Z. \& Dickmann, D. I. 1992. Responses of two hybrid Populus clones to flooding, drought and nitrogen availability. I. Morphology and growth. Can. J. Bot., 70, 2265-2270.

Mencuccini, M. \& Grace, J. 1995. Climate influences the leaf area/sapwood area ratio in Scots pine. Tree Physiol., 15, 1-10.

Neumann, H. H., den Hartog, G. \& Shaw, R. H. 1989. Leaf area measurements based on hemispheric photographs and leaf-litter collection in a deciduous forest during autumn leaf-fall. Agric. For. Meteorol., 45, 325-345.

Niinemets, Ü. \& Kull, O. 1995. Effects of light availability and tree size on the architecture of assimilative surface in the canopy of Picea abies: variation in needle morphology. Tree Physiol., 15, 307-315.

Ross, J. \& Ross, V. 1998. Statistical description of the architecture of a fast growing willow coppice. Agric. Forest Meteorol., 91, 23-37.

Sampson, D. A. \& Allen, H. L. 1995. Direct and indirect estimates of leaf area index (LAI) for lodgepole and loblolly pine stands. Trees, 9, 119-122.

Sennerby-Forsse, L. 1995. Growth processes. Biomass Bioenergy, 9, 35-43.

Smith, N. J., Chen, J. M. \& Black, T. A. 1993. Effects of clumping on estimates of stand leaf area index using the LI-COR LAI-2000. Can. J. For. Res., 23, 1940-1943.

Tahvanainen, L. \& Rytkönen, V.-M. 1999. Biomass production of Salix viminalis in southern Finland and the effect of soil properties and climate conditions on its production and survival. Biomass Bioenergy, 16, 103-117.

Verwijst, T. \& Telenius, B. 1999. Biomass estimation procedures in short rotation forestry. For. Ecol. Manage., 121, 137-146.

Vose, J. M. \& Allen, H. L. 1988. Leaf area, stemwood growth and nutrition relationships in loblolly pine. For. Sci., 34, 547-563.

Welles, J. M. 1990. Some indirect methods of estimating canopy structure. Remote Sens. Rev., 5, $31-43$.

Welles, J. M. \& Norman, J. M. 1991. Instrument for indirect measurement of canopy architecture. Agron. J., 83, 818-825.

Willebrand, E., Ledin, S. \& Verwijst, T. 1993. Willow coppice systems in short rotation forestry: effects of plant spacing, rotation length and clonal composition on biomass production. Biomass Bioenergy, 4, 323-331. 


\title{
Lehepinna indeksi määramine pajuistanduses
}

\author{
Ebe Merilo, Katrin Heinsoo ja Andres Koppel
}

Aastatel 1995-1997 hinnati lehepinna indeksit (LAI) Saare (58 42' N, 26 55' E) pajuistanduse neljal katseruudul, mis esindasid kahte liiki (Salix viminalis ja Salix dasyclados) ning kahte väetustaset (väetamata ja väetatud). LAI otseseks määramiseks leiti allomeetrilised astmefunktsioonid võsu tüve diameetri ja lehestiku massi vahel või koguti lehevarist. Katseruutude allomeetriline LAI varieerus vahemikus 1,0-16,6, kusjuures väetatud ruutude LAI oli kõrgem kui väetamata ruutude LAI. Väetamata ruutudel oli lehevarise kogumisel saadud LAI umbes kaks korda suurem kui allomeetriline LAI. S. dasyclados'e väetatud ruudul ilmnes vastupidine seos: lehevarise andmetel arvutatud LAI oli väiksem kui allomeetriline LAI. Kaudselt (s.t kalasilma fotodelt) määratud LAI ülehindas tegelikku LAI-d väetamata ruutudel, kuid oluliselt alahindas seda väetatud ruutudel. Lehestiku agregatsiooniindeks ( $\Omega$; kaudselt määratud LAI/allomeetriline LAI) varieerus vahemikus 0,26-1,04. Uuritud meetoditest andis kõige täpsemad tulemused LAI määramise allomeetriline meetod, kusjuures on oluline, et 1) astmefunktsioonid võsu tüve diameetri ja lehestiku massi vahel leitakse iga liigi ja väetustaseme jaoks eraldi ning 2) lõigatud ja mõõdetud võsud ja taimed kajastavad adekvaatselt reaalset olukorda. 